\title{
Cloning of a proopiomelanocortin cDNA from the pituitary gland of the sea bass (Dicentrarchus labrax) and assessment of mRNA expression in different tissues by means of real-time PCR
}

\author{
S Varsamos, S E Wendelaar Bonga, G Flik, R Queré ${ }^{1}$ \\ and $\mathbf{T}$ Commes ${ }^{2}$ \\ Department of Animal Physiology, University of Nijmegen, Toernooiveld 1, 6525 ED Nijmegen, The Netherlands \\ ${ }^{1}$ Skuld Tech, Université Montpellier II, Place Eugène Bataillon, CC 091, 34095 Montpellier, France \\ ${ }^{2}$ IGH/UPR, CNRS 1142, 141 rue de la Cardonille, 34396 Montpellier cedex 5, France \\ (Requests for offprints should be addressed to G Flik; Email: gertflik@sci.kun.nl)
}

\begin{abstract}
Proopiomelanocortin (POMC) cDNA was cloned from sea bass (Dicentrarchus labrax) pituitary gland. A 743 nucleotide sequence was obtained coding for the following sequences flanked by sets of proteolytic cleavage sites: ACTH $\left(\mathrm{Ser}^{88}-\mathrm{Met}^{127}\right), \alpha-\mathrm{MSH}\left(\mathrm{Ser}^{88}-\mathrm{Gly}^{102}\right)$, CLIP $\left(\right.$ Pro $\left.^{106}-\mathrm{Met}^{127}\right), \beta-\mathrm{LPH}\left(\mathrm{Glu}^{131}-\mathrm{Gln}^{208}\right), \gamma$-LPH $\left(\mathrm{Glu}^{131}-\mathrm{Ser}^{175}\right), \quad \beta-\mathrm{MSH} \quad\left(\operatorname{Asp}^{159}-\mathrm{Ser}^{175}\right), \quad$ and $\beta$ endorphin $\left(\mathrm{Tyr}^{178}-\mathrm{Gln}^{208}\right)$. No region homologous to $\gamma-\mathrm{MSH} /$ joining peptide (a tetrapod POMC feature) was found. Amino acid sequence identity was high with other teleostean species considered (tilapia: 73\%) and lower with elasmobranchs (dogfish: 42\%). However, the presumed
\end{abstract}

biologically active peptides were highly conserved within all species considered: $\alpha-\mathrm{MSH}(93-100 \%)$, ACTH (8095\%) and $\beta$-endorphin (54-90\%). Real-time PCR allowed us to quantify the expression of the POMC in different tissues of the sea bass: pituitary gland, liver, gonad and head kidney. No significant POMC expression was found in the integument. In pituitary gland, gonads, head kidney and liver, POMC expression was respectively, $1.26 \times 10^{10}, \quad 2.67 \times 10^{5}, \quad 2.06 \times 10^{4}$ and $1.67 \times 10^{4}$ copies/ $\mu \mathrm{g}$ mRNA.

Journal of Endocrinology (2003) 176, 405-414

\section{Introduction}

The vertebrate brain controls the stress response through highly organized neuroendocrine structures. This control involves numerous pathways and humoral mediators that are characteristically activated in response to stressors, which are environmental or internal changes sensed as harmful and threatening. Activation of the hypothalamicpituitary-adrenal axis stimulates pituitary proopiomelanocortin (POMC)-derived peptide production and secretion; these peptides are involved in the mediation and regulation of the stress response (Wendelaar Bonga 1997, Slominski et al. 2000). The POMC gene is expressed predominantly in the pituitary gland. For cattle it has been shown that roughly $30 \%$ of all mRNAs of the anterior pituitary gland are derived from the POMC gene (Inoue et al. 1979). POMC is produced in the corticotrope cells of the pars distalis and the melanotrope cells of the pars intermedia. POMC mRNA is translated into a single protein product, the precursor of adrenocorticotropic hormone (ACTH), endorphins, melanotropins and lipotropins (Smith \& Funder 1988). These neuropeptides are differentially generated through successive cell-specific processing steps and post-translational modifications including endo- and exopeptidase cleavage, amidation and acetylation (for review see Slominski et al. 2000).

In general, mammals transcribe only one POMC gene per haploid genome (Drouin et al. 1989). In lower vertebrates such as fishes, some species were found to express two forms of the POMC gene that have different degrees of homology depending on species. In polyploid fishes (e.g. salmonids and carp) a second form of POMC is found (Salbert et al. 1992, Arends et al. 1998a) as in chondrostean species such as paddlefish and sturgeon in which that gene was duplicated (Alrubaian et al. 1999, Danielson et al. 1999). In mammals, transcription and translation of the POMC gene have been detected in peripheral tissues such as placenta, gonads, adrenals, spleen and skin (for review see Slominski et al. 2000). However, for fishes so far data have been presented on only peripherally localized POMC-derived peptides (Balm \& Pottinger 1995, Ottaviani et al. 1995, van den Burg et al. 2001), not on the messenger proper. 
The present study focuses on the POMC of sea bass (Dicentrarchus labrax), a member of the Moronidae family, which includes species of great biological and economic interest and that occur in the Atlantic Ocean and the Mediterranean Sea. One of the aims of this study was to determine the POMC gene sequence, which is important for future studies focusing on the role of POMC-derived peptides in the stress response of this species. Most of the known teleost POMC sequences concern stenohaline freshwater (carp) and euryhaline species (salmon, trout). Information on a truly stenohaline marine teleost POMC sequence was not available and such information would add to our understanding of POMC phylogeny. Moreover, determination of the sea bass POMC sequence is necessary for further investigations concerning the detection and quantification of the expression of this gene. Little is known about peripheral expression of the POMC messenger in fishes. Hence, we set out to detect and compare the expression of the POMC gene in different tissues by means of a quantification method based on real-time PCR, which appears to be much more sensitive and precise compared with classical techniques based on hybridization.

\section{Materials and Methods}

\section{Animals}

Adult sea bass $(350 \pm 45 \mathrm{~g})$ originated from IFREMER (Palavas les Flots, France) and were maintained in the aquaculture facilities of the University of Nijmegen, The Netherlands. The fish were held in 200 liter tanks with filtered and aerated artificial sea water, obtained by addition of natural salt (Aquarium Systems, France) to tap water. The temperature was set at $20{ }^{\circ} \mathrm{C}$ and photoperiod to $12 \mathrm{~h}$ light: $12 \mathrm{~h}$ darkness. The fish were fed commercial pellets, at a ration of $2 \%$ body weight per day. Animals were rapidly killed by decapitation. Tissues (pituitary gland, gonads, liver, head kidney and integument) for mRNA extraction were rapidly dissected, weighed and frozen in liquid nitrogen.

\section{$m R N A$ extraction and $c D N A$ synthesis}

Poly-adenylated RNA isolation was performed with Dynal's Dynabeads mRNA Direct kit (Dynal, Norway). Briefly, tissues were disrupted in a lysis buffer. Cellular lysate was centrifuged for $5 \mathrm{~min}$ at $800 \mathrm{~g}$ to eliminate cellular debris. The supernatant was transferred to a tube containing prewashed Dynabeads oligo $(\mathrm{dT})_{25}$, incubated for $20 \mathrm{~min}$ on a rotary agitator to anneal and washed (five times). For synthesis of first-strand cDNA annealed mRNAs were incubated for $2 \mathrm{~min}$ at $37^{\circ} \mathrm{C}$ with a reverse transcription (RT)-Mix $\left(11 \mu \mathrm{l} \mathrm{H} \mathrm{H}_{2} \mathrm{O}, 4 \mu \mathrm{l}\right.$ R buffer, $2 \mu \mathrm{l}$ dithiothreitol, $1 \mu \mathrm{ldNTP}$ ) and then transferred to $37^{\circ} \mathrm{C}$ for
$1 \mathrm{~min}$. Finally, $2 \mu \mathrm{l}$ Superscript II reverse transcriptase (200 U/ $\mu \mathrm{l}$; Invitrogen) were added and the mixture was incubated at $37^{\circ} \mathrm{C}$ for $1 \mathrm{~h}$. The resulted cDNAs were stored at $-20{ }^{\circ} \mathrm{C}$.

\section{PCR for gene-specific primers determination}

To determine sea bass POMC-specific primers, PCR using a thermocycler (Hybaid, UK) was performed on cDNA obtained from sea bass pituitary mRNA with the following degenerated primers: forward $5^{\prime}$-ATG GAR CAY TTY GCN TGG GG-3' and reverse 5'-TGS YTC ATT TTG TAG GAG CC- $3^{\prime}$, designed on the basis of consensus POMC sequences. Template DNA $(1 \mu \mathrm{l}$ RT product) and $25 \mathrm{pmol}$ of each primer were used in a final volume of $50 \mu \mathrm{l}$ containing $1 \times$ PCR buffer, $2.5 \mathrm{mM}$ $\mathrm{MgCl}_{2}, 100 \mu \mathrm{M}$ (each) dNTPs and 2.5 units Taq DNA polymerase (Promega). After an initial denaturing step at $95^{\circ} \mathrm{C}$ for $2 \mathrm{~min}, 40$ cycles of $95^{\circ} \mathrm{C}$ for $30 \mathrm{~s}, 50{ }^{\circ} \mathrm{C}$ for 30 s and $72{ }^{\circ} \mathrm{C}$ for $1 \mathrm{~min}$ were performed. A final extension step of $72{ }^{\circ} \mathrm{C}$ for 2 min was carried out. PCR products were analyzed by electrophoresis on 1.5\% agarose/ ethidium bromide gel, cloned and sequenced (see below). The obtained sequences (227 bp) were compared with POMC sequences of other species and sea bass POMCspecific primers were determined for the GeneRacer protocol (see below): 5'Dlp (5'-AAG CCT GTT GGA CGA AAG C-3'), 3'Dlp (5'-GAG CCA TCC TTC TTC TCG TG-3'), 5'Dlpnest (5'-CCG GTC AAA GTC TTC ACC TC-3') and $3^{\prime}$ Dlpnest $\left(5^{\prime}\right.$-ACC TCC TGT GCC TTC TCC TC-3').

\section{Cloning, transformation, purification and sequencing of PCR products}

PCR products were ligated into pCR4-TOPO plasmid vector and transformed into chemically competent TOP 10 Escherichia coli cells (TOPO TA Cloning kit; Invitrogen). After selection on LB-ampicillin agar, transformed cells were screened for appropriate size inserts using a thermocycler and M13 sense and antisense primers (20 pmol each in a final volume of $50 \mu \mathrm{l})$. The PCR profile consisted of a denaturing step at $95^{\circ} \mathrm{C}$ for $2 \mathrm{~min}$, a step $\left(35\right.$ cycles) comprising denaturing at $95^{\circ} \mathrm{C}$ for $30 \mathrm{~s}$, annealing at $56{ }^{\circ} \mathrm{C}$ for $30 \mathrm{~s}$ and extension at $72{ }^{\circ} \mathrm{C}$ for $1 \mathrm{~min}$ and a final extension step at $72{ }^{\circ} \mathrm{C}$ for $2 \mathrm{~min}$. Sequencing of PCR products was performed by the ddNTP procedure (Genome Express, France). For the needs of the RT-PCR (see below), PCR products were purified by MiniPreps (Promega) and isolated plasmids were stored at $-20{ }^{\circ} \mathrm{C}$.

\section{Sea bass POMC sequence determination}

Sea bass pituitary POMC sequence was determined using the GeneRacer protocol (GeneRacer kit; Invitrogen), 
designed for full-length, RNA ligase-mediated amplification of $5^{\prime}$ and $3^{\prime}$ ends. Briefly, isolated sea bass pituitary mRNA was submitted to the following treatments according to the GeneRacer protocol: (i) dephoshorylated by treatment with calf intestinal phosphatase to eliminate truncated mRNA and non-mRNA, (ii) the $5^{\prime}$ cap structure from intact full-length mRNA was removed, (iii) a GeneRacer RNA-oligo was ligated to the $5^{\prime}$ end of the mRNA; this oligo provided known priming sites for GeneRacer PCR primers after transcription of the mRNA into cDNA, (iv) RT with a GeneRacer oligo dT primer $(50 \mathrm{mM})$ (containing a dT tail to prime the first-strand cDNA synthesis in the RT reaction and known priming sites at $5^{\prime}$, for GeneRacer PCR 3' primers). $5^{\prime}$ and $3^{\prime}$ PCR were performed using genespecific and GeneRacer ligated primers (see above). Template DNA (1 $\mu \mathrm{l}$ RT product), 20 pmol gene-specific primer and $60 \mathrm{pmol}$ GeneRacer primer were used in a final volume of $50 \mu \mathrm{l}$ containing $1 \times$ PCR buffer, $2.5 \mathrm{mM}$ $\mathrm{MgCl}_{2}, 100 \mu \mathrm{M}$ (each) dNTPs and 2.5 units Taq DNA polymerase. The PCR profiles included: (i) one cycle at $95{ }^{\circ} \mathrm{C}$ for $2 \mathrm{~min}$, (ii) five cycles of denaturing at $95^{\circ} \mathrm{C}$ for $30 \mathrm{~s}$ followed by $1 \mathrm{~min}$ at $72^{\circ} \mathrm{C}$, (iii) five cycles of denaturing at $95^{\circ} \mathrm{C}$ for $30 \mathrm{~s}$ followed by $1 \mathrm{~min}$ at $70^{\circ} \mathrm{C}$, and (iv) 25 cycles of denaturing at $95^{\circ} \mathrm{C}$ for $30 \mathrm{~s}$, annealing at $65^{\circ} \mathrm{C}$ for $30 \mathrm{~s}$ and elongation at $72{ }^{\circ} \mathrm{C}$ for $1 \mathrm{~min}$. A final elongation step was carried out at $72{ }^{\circ} \mathrm{C}$ for $5 \mathrm{~min}$. PCR products were analyzed by electrophoresis on 1.5\% agarose/ethidium bromide gel. One microliter of the amplified PCR product was used for $5^{\prime}$ and $3^{\prime}$ nested PCR to eliminate artifacts in the previous PCR. The same thermal profile and PCR mix composition were used except that in this case equal quantities $(20 \mathrm{pmol})$ of gene-specific nested primer and GeneRacer nested primer were added in the PCR mix. PCR products were analyzed, cloned and sequenced (see above).

\section{DNA sequences analysis}

To minimize errors due to nucleotide mis-incorporation by Taq DNA polymerase, the full-length sequence represents a consensus of multiple overlapping clones. Nucleotide sequences and deduced protein sequences were checked for similarities to known genes using BLAST algorithms at NCBI, EMBL and SWISS-PROT databases. The nucleotide and amino acid sequences of sea bass POMC reported in our study were aligned with the POMC sequences obtained from the databases mentioned above.

\section{Phylogenetic trees}

The neighbor-joining method was used for the construction of phylogenetic trees. They were calculated using the programs PROTDIST and NEIGHBOR from the PHYLIP package (Felsenstein 1993). One thousand boot- strap samples were created using SEQBOOT and PROTDIST, reconstructed with NEIGHBOR and a consensus tree was constructed with the CONSENSE program. Maximum-likelihood trees were constructed using the program PROTML from the MOLPHY package.

Detection and quantification of POMC expression in different tissues of sea bass

Detection and quantification of POMC expression was carried out on sea bass cDNAs from pituitary, head kidney, liver, gonads and integument, by means of real-time PCR with a Light Cycler (Roche). All measurements were performed in triplicate.

Control gene A control gene was necessary for the global calibration of the quantification by real-time PCR. The control gene of choice was the L17 ribosomal protein (AF139590), a sea bass housekeeping gene sequence downloaded from Genbank. Specific primers (5'DlL17rp (5'-GAG GAC GTG GTG GTT CAT CT- $\left.3^{\prime}\right)$ and 3'DlL17rp (5'-CTG GCT TGC CTT TCT TGA CT$\left.3^{\prime}\right)$ ) were determined on these sequences and tested by PCR on sea bass pituitary cDNA. A $201 \mathrm{pb}$ PCR product was cloned and sequenced. After verification plasmids (L17rp) were purified by MiniPreps (Promega) and their concentration was determined by absorbance measured at $260 \mathrm{~nm}$ with a spectrophotometer (Safas 190 DES, Monaco) and on agarose/ethidium bromide gel. Dilutions of the L17rp plasmid were used in real-time PCR experiments on sea bass POMC to obtain the calibration curve. Twenty microliter reactions were run containing $2 \mu \mathrm{l} 10 \times$ PCR Mix (containing SYBR Green and purchased from Roche), $1.6 \mu \mathrm{l} 25 \mathrm{mM} \mathrm{MgCl}{ }_{2}$ stock solution and $10 \mathrm{pmol}$ of each primer and $1 \mu \mathrm{l}$ template DNA (plasmid or cDNA from specific tissue). The thermal profile used for real-time PCR consisted of a step at $95{ }^{\circ} \mathrm{C}$ for $10 \mathrm{~min}$ and 40 cycles of denaturing at $95^{\circ} \mathrm{C}$ for $15 \mathrm{~s}$, annealing at $62{ }^{\circ} \mathrm{C}$ for $4 \mathrm{~s}$ and elongation at $72{ }^{\circ} \mathrm{C}$ for $8 \mathrm{~s}$. After the last cycle, temperature in the Light Cycler chamber increased to $95^{\circ} \mathrm{C}$ and then decreased to $62{ }^{\circ} \mathrm{C}$ for $30 \mathrm{~s}$. Then it was increased gradually to $95^{\circ} \mathrm{C}$ to obtain the melting curves of the amplified fragments. Absence of non-specific PCR products and primer dimers was checked by the melting curves (see Fig. 5) and by electrophoresis on $8 \%$ acrylamide/SYBR Green gel.

POMC gene For real-time PCR internal calibration, a fragment of $128 \mathrm{bp}$ was amplified by classical PCR on sea bass pituitary cDNA with the following primers: $5^{\prime}$ Dlpnest and $3^{\prime}$ Dlpnest (see above). PCR product was cloned, sequenced and after verification plasmids were purified and its concentration was determined on agarose/ethidium bromide gel. Dilutions of this plasmid were used in real-time PCR experiments on sea bass POMC, to obtain 
GAA GTG GAG GGG ACA GAA ATC TTT GTC CAA CAg CTG AAC AAC AAg AAA ACA ACA

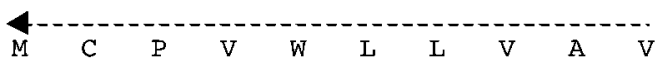

Signal peptide $\mathrm{A}_{\mathrm{A}} \mathrm{G}$ V A $\mathrm{R}$ G A $\mathrm{V}$ G $\mathrm{Q}$ C $\mathrm{L}$ E $\mathrm{H}$ P GCG CTG GCG GGC GTG GCC AGA GGA GCT GTT GGT CAG TGT TTG GAA CAT CCC AGC 162

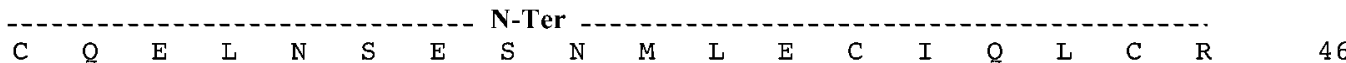
TGT CAG GAG CTC AAC TCT GAg AGC AAT ATG CTG GAg TGT ATC CAG CTC TGT CGC 216

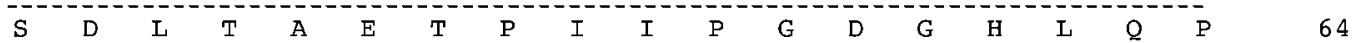

TCC GAC CTC ACC GCA GAG ACA CCG ATC ATC CCG GGC GAT GGC CAC CTC CAA CCT 270

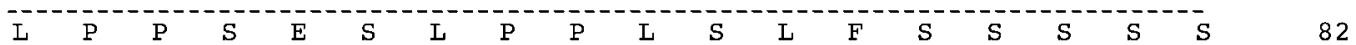

CTT CCT CCG TCA GAG TCT CTG CCT CCC CTC TCC CTG TTC TCT TCC TCC TCC TCT 324

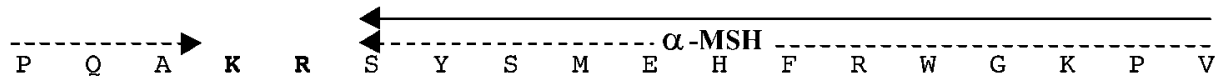
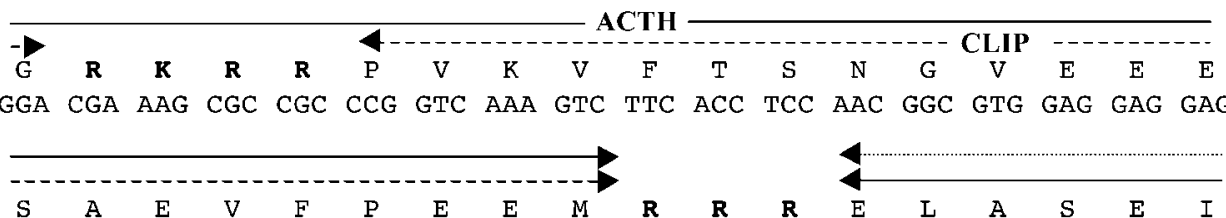

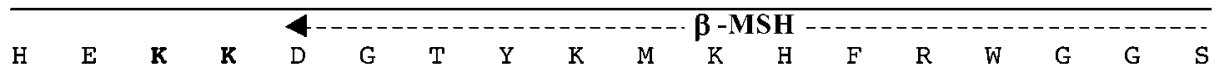
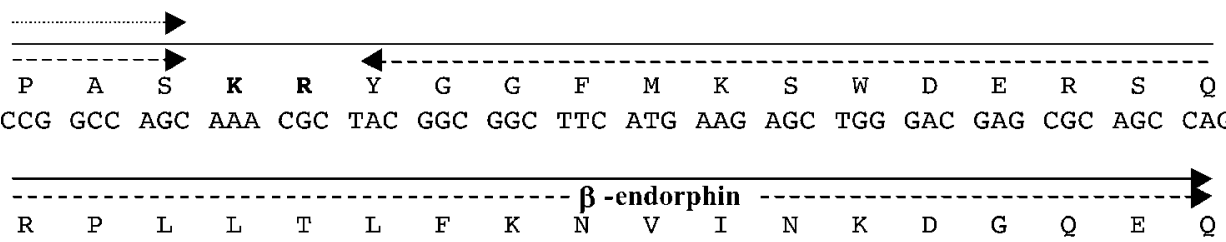

$\begin{array}{lllll}\mathbf{R} & \mathbf{R} & \mathrm{E} & \mathrm{Q} & *\end{array}$

Figure 1 Nucleotide and deduced amino acid sequences of sea bass POMC cDNA. Both sequences are numbered at the end of each line. The deduced POMC sequence is shown above the CDNA sequence. The POMC-derived peptides are shown: ACTH $\left(\right.$ Ser $^{88}-$ Met $\left.^{127}\right), \alpha-\mathrm{MSH}\left(\mathrm{Ser}^{88}{ }^{8} \mathrm{Gly}^{102}\right), \mathrm{CLIP}\left(\mathrm{Pro}^{106}-\mathrm{Met}^{127}\right), \beta$-LPH $\left(\mathrm{Glu}^{131}-\mathrm{Gln}^{208}\right), \gamma$-LPH $\left(\mathrm{Glu}^{131}-\mathrm{Ser}^{175}\right), \beta-\mathrm{MSH}\left(\mathrm{Asp}^{159}-\mathrm{Ser}^{175}\right)$ and $\beta$-endorphin $\left(\mathrm{Tyr}^{178}-\mathrm{Gln}^{208}\right)$. Potential proteolytic cleavage sites are shown in bold. 

1
1516
$\begin{array}{ll}30 & 31\end{array}$
$45 \quad 46$
6061
7576
90

1 Seabass ------MCPVWLLV AVALAGVARGAVGQC LEHPSCQELNSESNM LECIQLCRSDLTAET PIIPGDGHLQPLPPS ES----LPPLSLF-2 Tilapia ------MCPVWLFV ALVVVGGAREAVSQC WEHPSCQELSSESNM MECIQLCHSDLTAET PVIPGNAHLQPAVPS D---------------3 Salmon ------MLCPAWLL AVAVVGVVRGVKGQC WENPRCHDLSSENSI LECIQLCRSDLTTKS PIFPVKVHLQPPYPS DS----PPLYLPLSL 4 Carp MVRGERMLCPAWLLA LAVLCAAGSEVRAQC MEDARCRDLTTDENI LDCIQLCRSDLTDET PVY PGESHLQPPSEL EQ----TEVLVPLSP 5 Sturgeon ---MLRPVWGCVVAV MGVLWFYCSGVQSQC WEHSOCRDLSSEANI LECIQACKVDLSAES PLF PGNGHLQPTSED IEGASTTLSVLLEAL 6 Lungfish ---MLKPVWRHLFVL SAVLMIYGTGVHSQC WETSKCRDLSTESNL LECI KSCKSDLSAES PVY PGNGHMQPLSED IEDGYKTPLLSIIPA

7 Dogfish --MMQQSMWRSVLVV LCMVWARSSGQLREC WDHTKCRQLTSAPKL MECIEACKVEKTLES PIYPGNGHTEPIAES LEDEPVRAFLNHLPA

8 Human --MPRSCCSRSGALL LALLLQASMEVRGWC LESSQCQDLTTESNL LECI RACKPDLSAET PMF PGNGDEQPLTEN PEDVSAGEDCGPLPE

9 Bovine --MPRLCSSRSGALL LALLLQASMEVRGWC LESSQCQDLTTESNL LACIRACKPDLSAET PVF PGNGDEQPLTEN PEEEVAVGEG-----

10 Rat --MPRFCNSRSGALL LALLLQTSIDVWSWC LESSOCQDLTTESNL LACIRACRLDLSAET PVF PGNGDEQPLTEN PAEEETAGGD-----

11 Chicken ---MRGALCHSLPVV LGLLLCHPTTASGPC WENSKCODLATEAGV LACAKACRAELSAEA PVY PGNGHLQPLSES IEEVAGLALPAASPH

12 GiantToad ---MLQPGWRCILTI LGAFIFHVGEVKSQC WESGKCADLTSEDGI LECI KDCKMVLSAES PVF PGNGHMQPLSEN IEDIANYPIFNLFPT

\begin{tabular}{|c|c|c|c|c|c|c|c|}
\hline & & & & & & & \\
\hline & & -- & SYSM & HFRWGKPVGRKRR & VVEEESAE & VFPEEMRR & IAA \\
\hline & & & SSQAKRSYSM & . & GVAEESAE & PEEMRRRELTNEL & LAEEG-- \\
\hline & t & 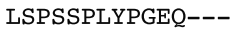 & ISYSM & $\mathbf{F r}$ & EEES & AFP SEM & $L-$ \\
\hline & Carp & P- & RSYSM & HFRY & GEE & NEI & YFQ \\
\hline & on & SEEEE & KRSYSM & IFRWGKP & VEEESAE & SYPAEI & QG- \\
\hline & 2 & ED--- & RRSYSM & HFRWGKP & MEDESAE & DMPMEFD & -- \\
\hline & og & EE--M & RSYSM & RKRRP & EDESVE & :VDFD & VVE--- \\
\hline & Huma & GAK- & $---P G P F$ & GKKRRP & EDESAE & TGQRL & GDGI \\
\hline & Bovine & $---\mathrm{P}$ & $--T G P$ & $\mathbf{R} \mathbf{P}$ & DESAQ & ERL & ARGPEAQAES \\
\hline & Rat & $\cdots$ & -- & $\mathbf{F} \mathbf{R}$ & VYP- & - & - \\
\hline & & & SM & & P-NG & DGD & G- \\
\hline & & NDNQNTQDGNME & ---LRRQDN KRS & RWGKPV & KVF PS-DAEEE & STEYRRELSVEFD & $---D T N-$ \\
\hline
\end{tabular}

12 GiantToad NDNQNTQDGNMEEE- ---LRRQDNKRSYSM EHFRWGKPVGKKRRP IKVFPS-DAEEES SE IXPTEYRRELSVEFD YP----DTN-------

\begin{tabular}{|c|c|c|c|c|c|c|c|}
\hline & & 95 & 6 & 1 & 26 & & 6 \\
\hline & & ---EEKAQEVAEEE & --- & -- & --LHEKKD & GTYKMKHFR & SKRY \\
\hline & a & --EKAQEMVEGAE & $\mathrm{EE}--$ & & ---QQLLNGVQEKKD & GSYKMKHFRWSGPPA & SKRYGGFMKSWDERS \\
\hline & al & ---EAGTAEGGEAE & GT- & & FFSLQEKKD & GSYKMNHFRWSGPPA & SKRYGGFMKSWDERS \\
\hline & $\operatorname{arp}$ & -- EE-----GALN & Q-- & 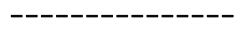 & $---Q D K K D$ & GSYKMS HF RWS SPPA & SKRYGGFMKSWDERS \\
\hline & on & ---- EELEEVFGGEN & DL-------- & ------ & -- -LQEKKD & SYKMNHFRWSGPPK & KSWDERS \\
\hline & Lun & -- EPSSEEKSEEN & 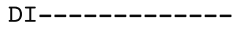 & ----- & --LLEKKD & ISPPK & IDERS \\
\hline & & EEMLE & DAGPKG & TQPMQ & VKKDG & $\mathrm{LK}$ & QRG \\
\hline & & $--t$ & 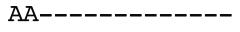 & & & & KS \\
\hline & & & --- & -----1 & $---E K K D S$ & PPK & S- -EKS \\
\hline & & EQVLE & 1----- & $\cdots$ & ---TEKAD & FRWGNPPK & S--EKS \\
\hline & & -- EEEEEEEEEEG & ------------- & ------------- & ----------EKKDG & Y RMR HF RWHAPLK & RYGGFMSL--EHS \\
\hline & & EDMDDS & & & & & 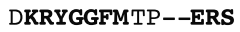 \\
\hline
\end{tabular}

$\begin{array}{rllll} & & & \\ 1 & \text { Seabass } & \text { QRPLLTLFKNVINKD } & \text { GQEQKREQ-- } & 212 \\ 2 & \text { Tilapia } & \text { QKPLLTLFKNVINKE GQQQK----- } & 208 \\ 3 & \text { Salmon } & \text { QKPLLTLFKNVIIKD GQQ-KREQ-- } & 230 \\ 4 & \text { Carp } & \text { QKPLLTLFKNVINKE } & \text { HQ--KKDQ-- } & 222 \\ 5 & \text { Sturgeon } & \text { QKPLLTLFKNVMIKD GHE-KKGQ-- } & 238 \\ 6 & \text { Lungfish } & \text { QKPLMTLFKNVMIKD AYE-KKGQ-- } & 231 \\ 7 & \text { Dogfish } & \text { QKPLLTLFRNVIVKD GHE-KKAQSQ } & 275 \\ 8 \text { Human } & \text { QTPLVTLFKNAIIKN AY--KKGE-- } & 237 \\ 9 & \text { Bovine } & \text { QTPLVTLFKNAIIKN AH--KKGQ-- } & 234 \\ 10 & \text { Rat } & \text { QTPLVTLFKNAIIKN VH--KKGQ-- } & 207 \\ 11 & \text { Chicken } & \text { QTPLMTLFKNAIVKS } & \text { AY--KKGQ-- } & 226 \\ 12 & \text { GiantToad } & \text { QTPLMTLFKNAIIKN } & \text { AH--KKGQ-- } & 229\end{array}$

Figure 2 Alignment of POMC amino acid sequences from different species. Amino acids identical to the sea bass sequence are shown in bold. The accession number of the sequences used in the comparison and the percentage of their similarity with the sea bass sequence were: tilapia (Oreochromis mossambicus, AF116240; 73\%), salmon A (Oncorhynchus nerka, Okuta et al. (1996); 65\%), carp I (Cyprinus carpio, CAA74968; 57\%), sturgeon (Acipenser transmontanus, P87352; 54\%), lungfish (Protopterus annectens, 50\%), dogfish (Squalus acanthias, Amemiya et al. (1999); 42\%), human (Homo sapiens, P01189; 44\%), bovine (Bos taurus, P01190; 49\%), rat (Rattus norvegicus, P01194; 44\%), chicken (Gallus gallus, BAA34366; 46\%), giant toad (Bufo marinus, AAF06345; 45\%). $\gamma$ - and $\delta$-MSH sequences were removed (when present) from the sequences before alignment.

the calibration curve. Real-time PCR profile and mix composition were equivalent to those described for the control gene.
Quantification and analysis Quantification and analysis of the results were performed with the computer device of the Light Cycler (Light Cycler Relative Quantification 
Table 1 Amino acid sequence similarity between sea bass and POMC sequences of other species

\begin{tabular}{|c|c|c|}
\hline & Accession number & Similarity (\%) \\
\hline \multicolumn{3}{|l|}{ Species } \\
\hline Tilapia & AF116240 & 73 \\
\hline Carp I & CAA74968 & 55 \\
\hline Sturgeon & P87352 & 55 \\
\hline Lamprey & 151117 & 29 \\
\hline Lungfish & AAD29144 & 48 \\
\hline Giant toad & AAF06345 & 44 \\
\hline Chicken & BAA34366 & 45 \\
\hline Rat & P01194 & 45 \\
\hline Bovin & P01190 & 46 \\
\hline Human & P01189 & 45 \\
\hline
\end{tabular}

Software 1.0; Roche) and calculations were done according to Rasmussen (2001). The POMC messenger quantification was expressed in a number of copies/ $\mu \mathrm{g}$ mRNA.

\section{Results}

\section{POMC sequence}

A single form of functional POMC gene was found to be expressed in sea bass. Using the sea bass pituitary cDNA library as template, the GeneRacer protocol resulted in the amplification of a 522 (5' RACE) and a 349 ( $3^{\prime}$ RACE) nucleotide product. Five clones of each product were sequenced to minimize erroneous nucleotide incorporation by Taq DNA polymerase. The $5^{\prime}$ product contained the signal peptide, $\mathrm{N}$-terminal and $\alpha$-melanocytestimulating hormone $(\alpha-\mathrm{MSH})$ sequences, the $3^{\prime}$ product contained the corticotropin-like intermediary peptide (CLIP) sequence from ACTH, $\beta-\mathrm{MSH}, \quad \beta-$ and $\gamma$-lipotropin $(\gamma-\mathrm{LPH})$ and $\beta$-endorphin sequences as well as a stop codon. Alignment of the overlapping sequences resulted in a final 743 nucleotide product containing an open reading frame encoding a 212 amino acid protein (Fig. 1). The open reading frame contained the following sequences flanked by sets of proteolytic cleavage sites indicating potential post-translational processing: ACTH $\left(\mathrm{Ser}^{88}-\mathrm{Met}^{127}\right), \alpha-\mathrm{MSH}\left(\mathrm{Ser}^{88}-\mathrm{Gly}^{102}\right)$, CLIP $\left(\mathrm{Pro}^{106}\right.$ $\left.\mathrm{Met}^{127}\right), \beta-\mathrm{LPH}\left(\mathrm{Glu}^{131}-\mathrm{Gln}^{208}\right), \gamma-\mathrm{LPH}\left(\mathrm{Glu}^{131}-\mathrm{Ser}^{175}\right)$, $\beta$-MSH $\left(\mathrm{Asp}^{159}-\mathrm{Ser}^{175}\right)$, and $\beta$-endorphin $\left(\mathrm{Tyr}^{178}\right.$ $\mathrm{Gln}^{208}$ ) (Fig. 1). Each of these regions contains small modifications, which seem to be unique to sea bass concerning amino acid substitution or number. No region homologous to $\gamma-\mathrm{MSH} /$ joining peptide was present. Figure 2 shows alignment of the sea bass POMC sequence with POMC sequences from other species. Amino acid sequence identity between sea bass POMC and POMC from other species varies according to the groups considered (Table 1). Similarity was high with known sequences of teleostean species (tilapia: 73\%) and low with those of mammals (human: 45\%). The biologically active peptides
$\alpha-\mathrm{MSH}$ (93-100\%), ACTH (80-95\%), and $\beta$-endorphin $(54-90 \%)$ are highly conserved among all species considered. Sea bass $\beta$-endorphin sequence displayed two additional amino acids compared with species other than fish, the one characteristic for ray-finned fish, i.e. the paired $\operatorname{Trp}^{185} \mathrm{Asp}^{186}$ and the $\mathrm{Glu}^{207}$ residue, as well as a monobasic consensus sequence $\mathrm{Glu}^{187} \mathrm{ArgSerGln}{ }^{190}$. The ACTH sequence displayed a putative phosphorylation consensus sequence $\mathrm{Ser}^{119} \mathrm{AlaGlu}^{121}$.

\section{Phylogenetic tree}

A consensus tree of 1000 bootstrap samples (Fig. 3) of the neighbor-joining program allowed us to determine the position of sea bass POMC sequence within the POMC family. All methods employed showed a configuration in which teleosts branched off separately. The bootstrap value of the node clustering the euryhaline sea bass and tilapia was $96 \cdot 2 \%$.

\section{POMC expression}

Real-time PCR allowed us to quantify the expression of the POMC in different tissues of the sea bass: pituitary gland, liver, gonad and head kidney (Figs 4 and 5). Values were calibrated by means of a housekeeping gene (control) present in all the tissues. The efficiencies of the real-time PCR procedure for the control gene and the POMC gene were high: 1.904 and 1.901 respectively. The lowest POMC expression was found in the liver. In pituitary, gonads and head kidney, POMC expression was respectively, $7 \cdot 5 \times 10^{5}$-, 1.6- and 1.2-fold higher compared with that in the liver. Expressed in terms of number of copies/ $\mu \mathrm{g}$ mRNA, POMC expression was $1.26 \times 10^{10}$ (pituitary), $2.67 \times 10^{5}$ (gonads), $2.06 \times 10^{4}$ (head kidney) and $1.67 \times 10^{4}$ (liver). The values measured for the integument (not shown) were below the background values of the standard curve. The real-time PCR approach allowed detection of less than ten copies of POMC mRNA.

\section{Discussion}

The GeneRacer technique allowed us to clone a single functional form of POMC from the pituitary gland of the European sea bass. A single form of that prohormone was also found in tilapia (Oreochromis mossambicus) (Lee et al. 1999a). However, in tetraploid teleost species such as carp (Cyprinus carpio) (Arends et al. 1998a), chum salmon (Oncorhynchus keta) (Kitahara et al. 1988) and trout (Oncorhynchus mykiss) (Salbert et al. 1992) two forms of POMC were found. In general, also in mammals only one form of POMC occurs (Drouin et al. 1989), although the mouse genome contains two non-allelic POMC $\alpha$ - and $\beta$-genes (Uhler et al. 1983). In some lower vertebrates such as chondrosteans (Alrubaian et al. 1999) two forms of POMC are found, but this is not a general phenomenon as the phylogenetically old dipnoid fishes (lung fishes) appear 


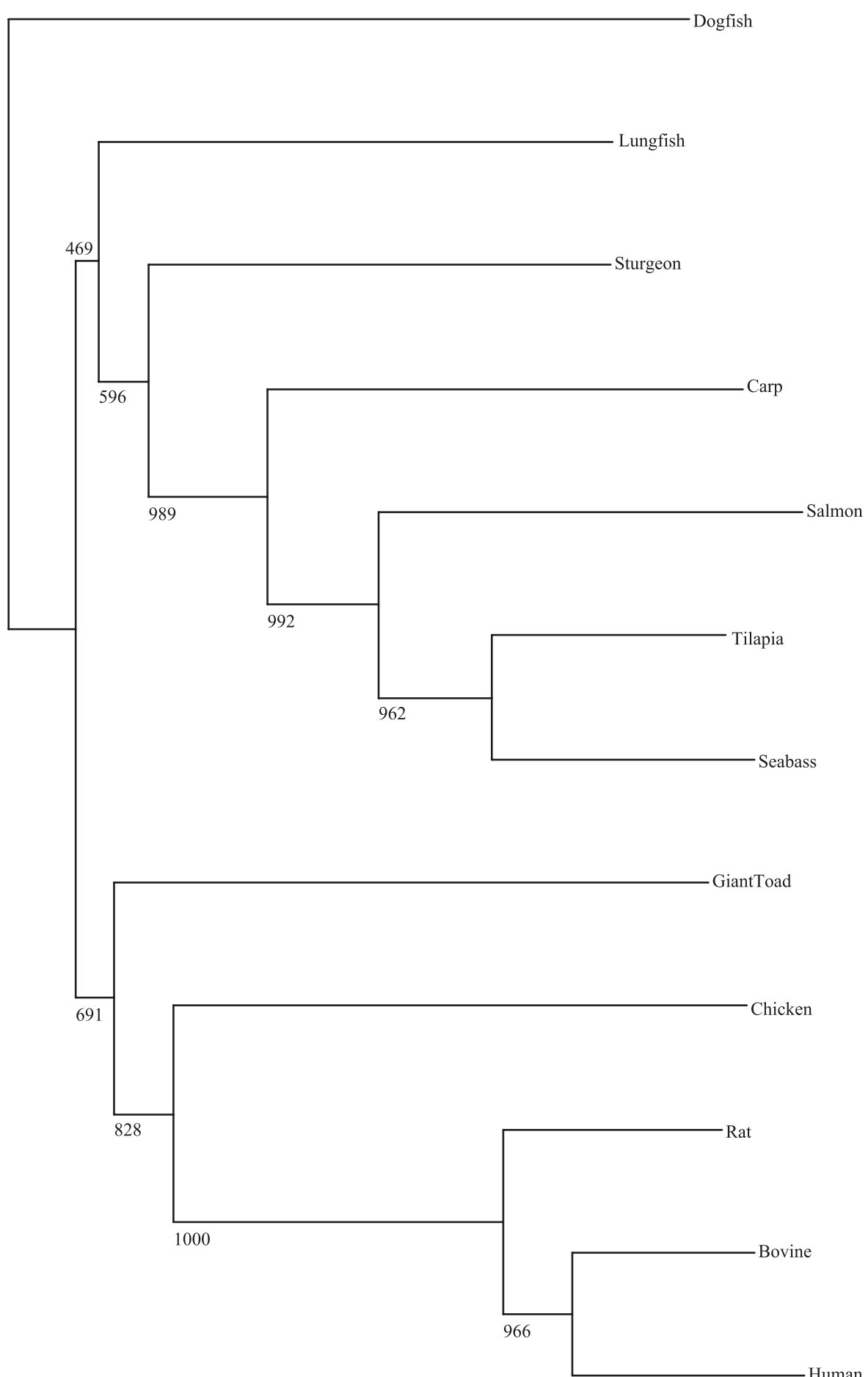

Figure 3 Phylogenetic tree of the POMC family based on amino acid sequences. $\gamma$ - and $\delta$-MSH sequences (when present) were removed from the sequences before alignment. Numbers in branches indicate the bootstrap values calculated with the neighbor-joining method. For accession numbers and Latin names of the species used in this study see Fig. 2. 


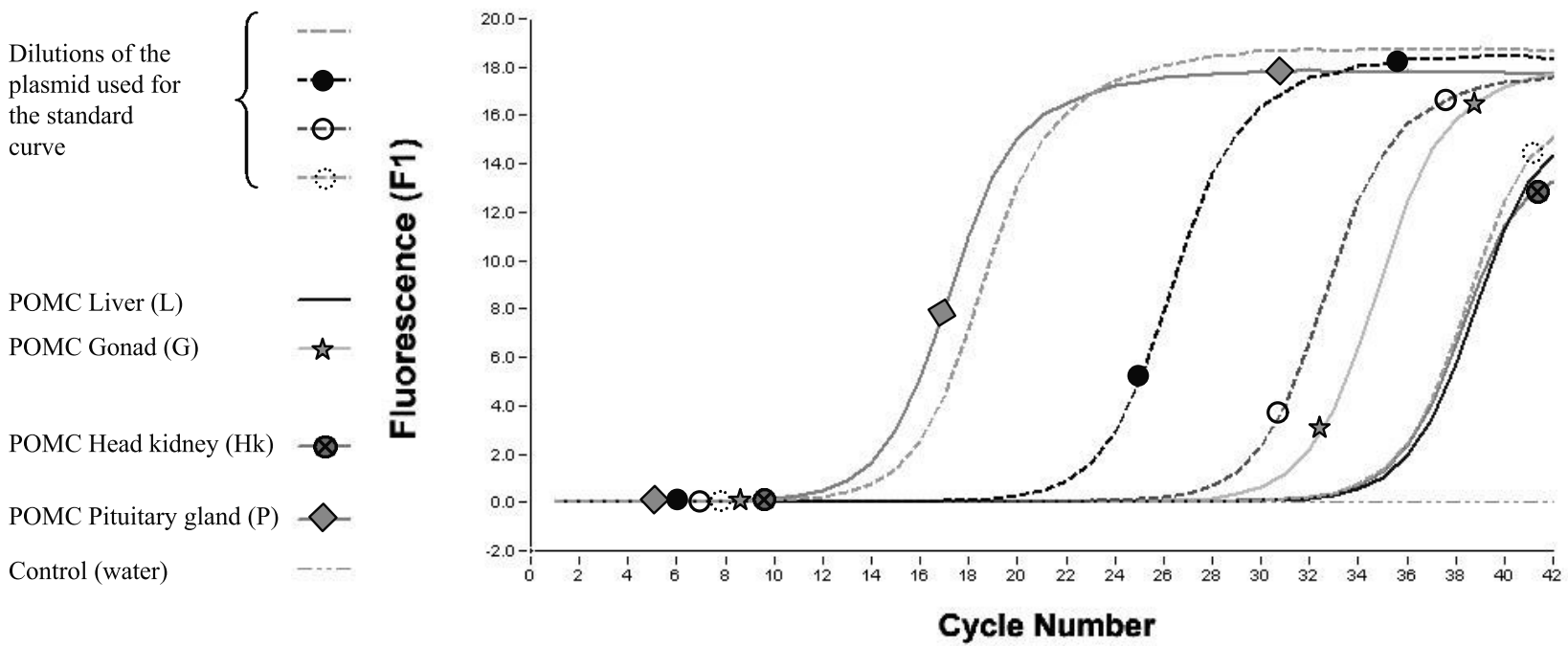

Figure 4 Real-time PCR analysis (Light Cycler) of sea bass POMC mRNA isolated from pituitary gland (P), liver (L), gonad (G) and head kidney $(\mathrm{Hk})$. One microliter of cDNA from each tissue was used as template for amplification of the POMC gene fragment. First the control gene L17rp was run and then the POMC templates were calibrated to the control gene in each of the samples. The number of PCR cycles required to obtain measurable amplification (P: 13,9 cycles; G 31,59 cycles; Hk: 34,9 cycles; L: 35,62 cycles) is related to the initial concentration of target POMC mRNA. Clearly, the results show that POMC is much more highly expressed in the pituitary gland than in other tissues. Water was used as negative control (red line). SYBR Green was used as fluorochrome.

to express only one form (Dores et al. 1999, Lee et al. 1999b).

Several recent studies have focused on the evolution of the POMC gene in vertebrates. In sea bass the POMC end product regions flanked by sets of basic amino acids were ACTH, $\alpha$ - and $\beta-\mathrm{MSH}, \beta-$ and $\gamma-\mathrm{LPH}$ and $\beta$-endorphin. The observed structure of the sea bass POMC corresponds to the ones reported in other teleost species. Overall, the substitutions, additions and deletions observed for the ACTH, $\beta$-MSH and $\beta$-endorphin regions are relatively few. However, the absence of $\gamma$-MSH sequence and most of the joining peptide region,

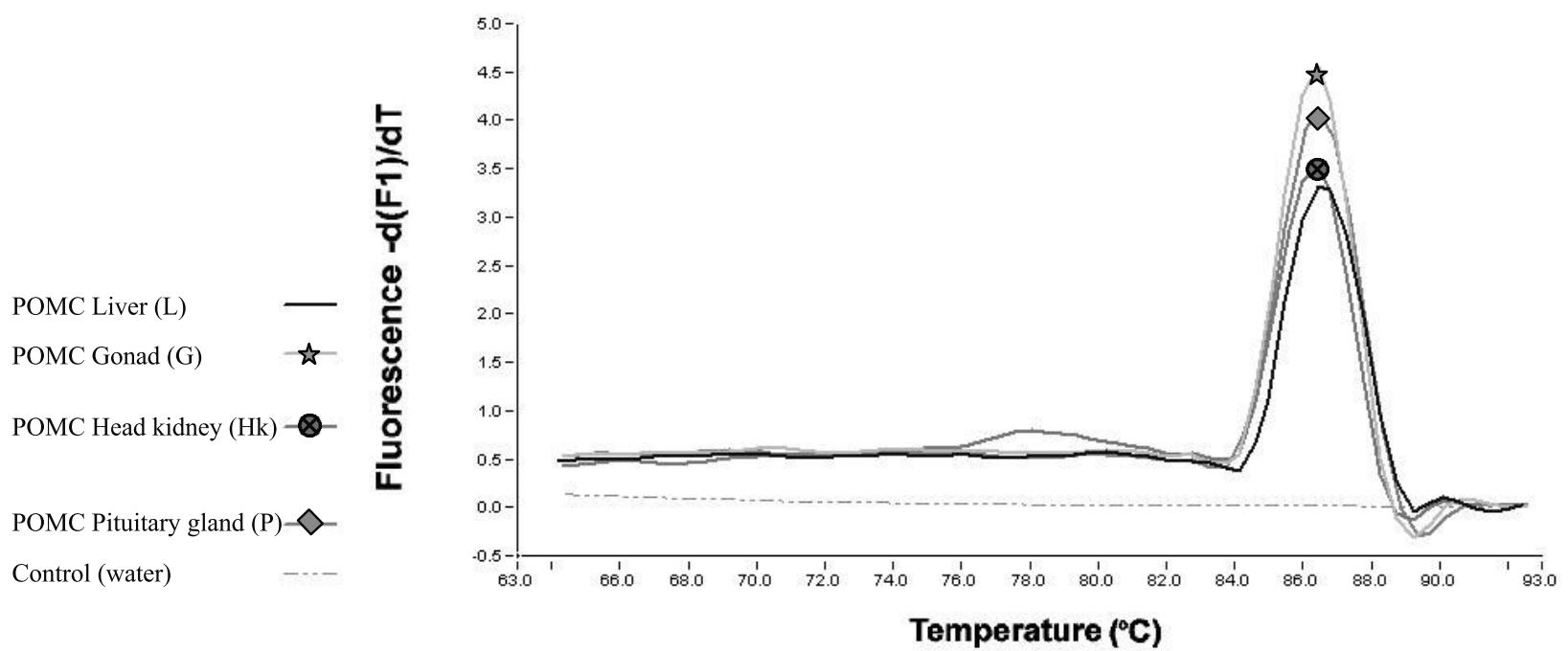

Figure 5 Melting curves of the PCR products from the RT-PCR displayed in Fig. 4. When temperature increases, double-stranded DNA dissociates, SYBR Green is liberated and fluorescence signal decreases. After the last cycle, temperature in the Light Cycler chamber was increased to $95{ }^{\circ} \mathrm{C}$ and then decreased to $62{ }^{\circ} \mathrm{C}$ for $30 \mathrm{~s}$ (maximum annealing). Then it was increased gradually to $95{ }^{\circ} \mathrm{C}$ to obtain the melting curves of the amplified fragments. When $50 \%$ of the double-stranded DNA is denatured, fluorescence decreases abruptly; the corresponding temperature is the Tm (melting temperature) of the PCR product. The Tm corresponds to the maximum of the curve: $-d$ (Fluorescence)/d(Temperature). All the PCR products of sea bass POMC from different tissues display the same Tm, indicating the absence of non-specific PCR products and primer dimers. 
set sea bass POMC and that of other teleostean fishes apart from the general organization of the prohormone. $\gamma-\mathrm{MSH}$ is also absent in jawless fishes such as the lamprey (Heinig et al. 1995) but it is present in gnathostomes, such as cartilaginous fishes (Squalus acanthias (Amemiya et al. 1999); Dasyatis akajei (Amemiya et al. 2000)), chondrosteans (as a remnant in Acipenser transmontanus (Amemiya et al. 1997)), neopterygians (as a remnant in Lepisosteus osseus (Dores et al. (1997)), amphibians (Rana ridibunda (Hilario et al. 1990)) and mammals (Nakanishi et al. 1979). When the internal duplication event occurred that gave rise to the $\gamma$-MSH sequence has not been determined so far. The absence of this MSH in the lamprey and its presence in species from the three major gnathostome radiations suggests that the $\gamma-\mathrm{MSH}$ duplication event occurred in an early Devonian ancestral gnathostome (Lee et al. 1999b). Since carp, salmon and sea bass first appeared during the Miocene, the important differences observed in POMC sequence of these species could be related to different ecological or physiological requirements and thus to different environmental constraints.

Although we found some significant differences, the sea bass POMC sequence displays a high degree of amino acid sequence identity with other groups when regions coding for biologically active peptides are considered. For example, the overall degree of amino acid identity with mammals was approximately $44 \%$, but this was much higher (67\%) when regions coding for $\mathrm{ACTH}, \beta-\mathrm{MSH}$ and $\beta$-endorphin were considered. The $\beta$-endorphin sequence in sea bass displays two amino acid insertions compared with amphibians, avians and mammals. This feature appears to be characteristic of all fish species examined so far. The physiological relevance of these additional amino acids in fish $\beta$-endorphin remains unknown. Five single basic amino acids (three lysines and two arginines) are present in the sea bass endorphin sequence, suggesting a putative posttranslational truncation by trypsin-like enzymes. This could give rise to several different endorphin signals as was reported in other fish species (van den Burg et al. 2001).

The phylogenetic analysis indicates that, although teleosts appeared long after the divergence of the main groups of gnathostome vertebrates, the sequence of the sea bass POMC has retained several features that are conserved in other vertebrates. The teleostean species considered in this study cluster in the phylogenetic tree. Among the ray-finned fish, the highest degree of speciation is observed in the teleosts (more than 30000 species identified up to today), which have settled in all kinds of aquatic niches. A role of a prohormone such as POMC in that successful radiation would implicate that it has been subject to selective evolutionary pressure.

Few studies have focused on POMC localization and expression in fish brain (Arends et al. 1998a,b, Ficele
1998). POMC-derived peptides are known to be involved in the development of the immune response (Weyts et al. 1999), as well as in the reproductive cycle (Mosconi et al. 1994). However, remarkably little is known about peripheral expression of POMC in fish. In mammals, transcription and translation of the POMC gene have been detected in a variety of peripheral tissues including placenta, uterus and gonads. There is evidence for involvement of locally produced POMC-derived peptides in the skin pigmentation and in the maintenance of skin integrity (Slominski et al. 2000), as well as in the regulation of the feto-maternal unit of the mammalian placenta (Petraglia et al. 1998). We were able to detect and quantify POMC mRNA expression in head kidney, liver and gonad (besides pituitary tissue) through the sensitive real-time PCR approach. Compared with other (semi-)quantitative techniques such as hybridization, capillary electrophoresis etc., the real-time PCR is much more convenient; most importantly its sensitivity allows the detection of roughly ten copies of the messenger under consideration. POMC expression was detected in all tissues but the integument; for the latter the values recorded were below the background values of the calibration curve. As anticipated, the concentration was found to be very much higher (roughly $10^{6}$-fold) in the pituitary gland than in the other tissues. To the best of our knowledge this is the first report on expression rate of POMC in the pituitary (as well as in other tissues) of a fish. The high rate of expression displayed by the prohormone gene in the pituitary gland was anticipated because of the involvement of this gland (via the pleiotropic POMC-derived peptides) to a variety of physiological processes including the stress response (Wendelaar Bonga 1997). On the other hand the expression rates measured in the peripheral tissues may reflect POMC expression activity of only a small but relevant subpopulation of cells in these tissues. Evidence is accruing for other (higher) vertebrates that both immune and neuroendocrine systems are able to produce POMC (reviewed in Blalock 1999). In that case, the presence of a POMC transcript in the head kidney of sea bass can be of great physiological relevance since this tissue constitutes, together with the thymus and the spleen, the major source of immune cells in fish. Recent work suggests that also in lower vertebrates (frog, Rana esculenta) extra-pituitary, peripherally produced and regulated POMC production contributes to the normal physiology, e.g. of the ovary (Nabissi et al. 2001). Thus, further studies on fishes with their phenomenal adaptive radiation and endless and subtle physiological adaptations are warranted to broaden our view on POMC-dependent processes.

\section{Acknowledgements}

S V was supported by a Marie Curie Individual fellowship (EU Project QLK5-CT-2000-52097). The authors would 
like to thank Dr Jacques Leunissen, Dr Olivier Elemanto and Dr Nicolas Galtier for their help.

\section{References}

Alrubaian J, Danielson P, Fitzpatrick M, Schreck C \& Dores RM 1999 Cloning of a second proopiomelanocortin cDNA from the pituitary of the sturgeon, Acipenser transmontanus. Peptides 20 431-436.

Amemiya Y, Takahashi A, Dores RM \& Kawauchi H 1997 Sturgeon proopiomelanocortin has a remnant of gamma-melanotropin. Biochemical and Biophysical Research Communications 230 452-456.

Amemiya Y, Takahashi A, Suzuki N, Sasayama Y \& Kawauchi H 1999 A newly characterized melanotropin in proopiomelanocortin in pituitaries of an elasmobranch, Squalus acanthias. General and Comparative Endocrinology 114 387-395.

Amemiya Y, Takahashi A, Suzuki N, Sasayama Y \& Kawauchi H 2000 Molecular cloning of proopiomelanocortin cDNA from an elasmobranch, the stingray, Dasyatis akajei. General and Comparative Endocrinology 118 105-112.

Arends RJ, Vermeer H, Martens GJ, Leunissen JA, Wendelaar Bonga SE \& Flik G 1998a Cloning and expression of two proopiomelanocortin mRNAs in the common carp (Cyprinus carpio L.). Molecular and Cellular Endocrinology 143 23-31.

Arends RJ, van der Gaag R, Martens GJ, Wendelaar Bonga SE \& Flik G 1998 b Differential expression of two pro-opiomelanocortin mRNAs during temperature stress in common carp (Cyprinus carpio L.). Journal of Endocrinology 159 85-91.

Balm PH \& Pottinger TG 1995 Corticotrope and melanotrope POMC-derived peptides in relation to interrenal function during stress in rainbow trout (Oncorhynchus mykiss). General and Comparative Endocrinology 98 279-288.

Blalock JE 1999 Proopiomelanocortin and the immune-neuroendocrine connection. Annals of the New York Academy of Sciences 885 161-172.

Danielson PB, Alrubaian J, Muller M, Redding JM \& Dores RM 1999 Duplication of the POMC gene in the paddlefish (Polyodon spathula): analysis of gamma-MSH, ACTH, and beta-endorphin regions of ray-finned fish POMC. General and Comparative Endocrinology 116 164-177.

Dores RM, Smith TR, Rubin DA, Danielson P, Marra LE \& Youson JH 1997 Deciphering posttranslational processing events in the pituitary of a neopterygian fish: cloning of a gar proopiomelanocortin cDNA. General and Comparative Endocrinology 107 401-413.

Dores RM, Sollars C, Danielson P, Lee J, Alrubaian J \& Joss JM 1999 Cloning of a proopiomelanocortin cDNA from the pituitary of the Australian lungfish, Neoceratodus forsteri: analyzing trends in the organization of this prohormone precursor. General and Comparative Endocrinology 116 433-444.

Drouin J, Nemer M, Charron J, Gagner JP, Jeannotte L, Sun YL, Therrien M \& Tremblay Y 1989 Tissue-specific activity of the pro-opiomelanocortin (POMC) gene and repression by glucocorticoids. Genome 31 510-519.

Felsenstein J 1993 PHYLIP (Phylogeny Inference Package). Department of Genome Sciences, University of Washington, http://evolution.genetics.washington.edu/phylip.html.

Ficele G, Heinig JA, Kawauchi H, Youson JH, Keeley FW \& Wright GM 1998 Spatial and temporal distribution of proopiomelanotropin and proopiocortin mRNA during the life cycle of the sea lamprey: a qualitative and quantitative in situ hybridization study. General and Comparative Endocrinology 110 212-225.

Heinig JA, Keeley FW, Robson P, Sower SA \& Youson JH 1995 The appearance of proopiomelanocortin early in vertebrate evolution: cloning and sequencing of POMC from a lamprey pituitary cDNA library. General and Comparative Endocrinology 99 137-144.

Hilario E, Lihrmann I \& Vaudry H 1990 Characterization of the cDNA encoding proopiomelanocortin in the frog Rana ridibunda. Biochemical and Biophysical Research Communications 173 653-659.
Inoue A, Kita T, Nakomura M, Chang A, Cohen SN \& Numa S 1979 Nucleotide sequence of cloned cDNA for bovine corticotropin-beta-lipotropin precursor. Nature 278 423-427.

Kitahara N, Nishizawa T, Iida K, Okazaki H, Andoh T \& Soma GI 1988 Absence of a gamma-melanocyte-stimulating hormone sequence in proopiomelanocortin mRNA of chum salmon Oncorhynchus keta. Comparative Biochemistry and Physiology B 91 365-370.

Lee J, Danielson P, Sollars C, Alrubaian J, Balm P \& Dores RM $1999 a$ Cloning of a neoteleost (Oreochromis mossambicus) pro-opiomelanocortin (POMC) cDNA reveals a deletion of the gamma-melanotropin region and most of the joining peptide region: implications for POMC processing. Peptides 20 1391-1399.

Lee J, Lecaude S, Danielson P, Sollars C, Alrubaian J, Propper CR, Lihrmann I, Vaudry H \& Dores RM 19996 Cloning of proopiomelanocortin from the brain of the African lungfish, Protopterus annectens, and the brain of the western spadefoot toad, Spea multiplicatus. Neuroendocrinology 70 43-54.

Mosconi G, Carnevali O, Facchinetti F, Radi D, Pestarino M, Vallarino M \& Polzonetti-Magni AM 1994 Ovarian melanotropic peptides and adaptation in two teleostean species: Sparus aurata L. and Dicentrarchus labrax L. Peptides 15 927-931.

Nabissi M, Soverchia L, Lihrmann I, Vaudry H, Mosconi G \& Polzonetti-Magni AM 2001 Evaluation of ovarian POMC mRNA through quantitative RT-PCR analysis in Rana esculenta. American Journal of Physiology. Cell Physiology 280 C1038-C1044.

Nakanishi S, Inoue A, Kita T, Nakamura M, Chang AC, Cohen SN \& Numa S 1979 Nucleotide sequence of cloned cDNA for bovine corticotropin-beta-lipotropin precursor. Nature 278 423-427.

Okuta A, Ando H, Ueda H \& Urano A 1996 Two types of cDNAs encoding proopiomelanocortin of sockeye salmon, Oncorhynchus nerka. Zoological Science 13 421-427.

Ottaviani E, Franchini A \& Franceschi C 1995 Evidence for the presence of immunoreactive POMC-derived peptides and cytokines in the thymus of the goldfish (Carassius c. auratus). Histochemistry Journal 27 597-601.

Petraglia F, Santuz M, Florio P, Simoncini T, Luisi S, Plaino L, Genazzani AR, Genazzani AD \& Volpe A 1998 Paracrine regulation of human placenta: control of hormonogenesis. Journal of Reproductive Immunology 39 221-233.

Rasmussen R 2001 Quantification on the Light Cycler. In Rapid Cycle Real-Time PCR: Methods and Applications, pp 21-34. Eds S Meuer, C Wittwer \& K Nakagawara. Berlin and Heidelberg: Springer-Verlag.

Salbert G, Chauveau I, Bonnec G, Valotaire Y \& Jego P 1992. One of the two trout proopiomelanocortin messenger RNAs potentially encodes new peptides. Molecular Endocrinology 6 1605-1613.

Slominski A, Wortsman J, Luger T, Paus R \& Solomon S 2000 Corticotropin releasing hormone and proopiomelanocortin involvement in the cutaneous response to stress. Physiological Reviews 80 979-1020.

Smith AI \& Funder JW 1988 Proopiomelanocortin processing in the pituitary, central nervous system, and peripheral tissues. Endocrine Reviews 9 159-179.

Uhler M, Herbert E, D'Eustachio P \& Ruddle FD 1983 The mouse genome contains two nonallelic pro-opiomelanocortin genes. Journal of Biological Chemistry 258 9444-9453.

van den Burg EH, Metz JR, Arends RJ, Devreese B, Vandenberghe I, Van Beeumen J, Wendelaar Bonga SE \& Flik G 2001 Identification of beta-endorphins in the pituitary gland and blood plasma of the common carp (Cyprinus carpio). Journal of Endocrinology 169 271-280.

Wendelaar Bonga SE 1997 The stress response in fish. Physiological Reviews 77 591-625.

Weyts FAA, Cohen N, Flik G \& Verburg-Van Kemenade BML 1999 Interactions between the immune system and the hypothalamopituitary-interrenal axis in fish. Fish and Shellfish Immunology 9 1-20.

Received in final form 18 November 2002 Accepted 21 November 2002 